\title{
PENGARUH BAHAN PENGISI TERHADAP MASSA CETAK TABLET VITAMIN C
}

\author{
Desy Nawangsari ${ }^{1}$ \\ ${ }^{1}$ Fakultas Kesehatan, Program Studi Sarjana Farmasi, Universitas Harapan \\ Bangsa \\ desynawangsari@uhb.ac.id
}

\begin{abstract}
ABSTRAK
Avicel ${ }^{\circledR}$ PH merupakan nama dagang dari selulosa mikrokristal yang umumnya digunakan dalam sediaan farmasi. Avicel ${ }^{\circledR} \mathrm{PH}$ banyak digunakan dalam pembuatan tablet secara kempa langsung karena memiliki laju alir dan kompresibilitas yang baik. Penelitian ini bertujuan untuk membandingkan pengaruh penggunaan Avicel $^{\circledR}$ PH 101 dan Avicel ${ }^{\circledR}$ PH 102 sebagai bahan pengisi pada sediaan tablet vitamin C. Metode penelitian ini dilakukan dengan membuat massa cetak tablet vitamin $\mathrm{C}$ dengan variasi bahan pengisi, kemudian massa cetak tersebut di evaluasi. Hasil yang diperoleh menunjukan penggunaan Avicel ${ }^{\circledR} \mathrm{PH} 102$ sebagai pengisi menghasilkan massa cetak yang lebih baik dilihat dari laju alir, sudut diam, carr's index dan hausner ratio.
\end{abstract}

Kata Kunci: Avicel ${ }^{\circledR} \mathrm{PH}$, Vitamin C, Granul

\section{ABSTRACT}

Avicel $^{\circledR}$ PH is branded name from microcrystalline cellulose that is generally used in pharmaceutical preparations. Avicel ${ }^{\circledR}$ PH are being used as filler or binder in dosage formulas in tablets especially for direct compression because having a good flowing rate and a good compressibility. This study aims to compare the influence of the use Avicel ${ }^{\circledR}$ PH 101 and Avicel ${ }^{\circledR}$ PH 102 as a filler on of preparations a tablet of ascorbic acid. A method of the research was conducted by making granule of ascorbic acid tablet with the variation filler, then the granule was evaluate in.The results showed Avicel ${ }^{\circledR}$ PH 102 as a filler produce granule which better seen from the flowability, static angle of repose, carr's index and hausner ratio.

Keywords: Avicel ${ }^{\circledR}$ PH, Ascorbic Acid, Granule

\section{PENDAHULUAN}

Metode kempa dalam pembuatan tablet menjadi pilihan utama bagi industri farmasi. Hal ini karena metode kempa langsung dinilai lebih efisien dan ekonomis (Siregar dan Wikarsa, 2010).

Syarat utama suatu bahan pengisi dapat digunakan untuk tablet cetak langsung adalah mempunyai sifat alir dan kompresibilitas yang baik (Gohel, 2005). Salah satu bahan yang umumnya digunakan yaitu Avicel ${ }^{\circledR} \mathrm{PH}$. Avicel $^{\circledR}$ PH merupakan nama dagang dari selulosa mikrokristal yang beredar dipasaran. (Siregar dan Wikarsa, 2010). Avicel dibuat dari hidrolisis terkontrol $\alpha$-selulosa dengan 
larutan asam mineral encer. Sebagai bahan farmasi Avicel ${ }^{\circledR} \mathrm{PH}$ digunakan untuk bahan pengisi tablet yang dibuat secara granulasi maupun

cetak langsung, bahan penghancur tablet, adsorben dan bahan anti lekat. (Rowe et.al., 2009). Avicel ${ }^{\circledR}$ PH 101 dan Avicel ${ }^{\circledR}$ PH 102 diketahui memiliki sifat alir dan kompresibilitas yang sangat baik. Perbedaan mendasar dari kedua jenis Avicel ${ }^{\circledR} \mathrm{PH}$ tersebut terletak pada ukuran partikel keduanya. Avicel ${ }^{\circledR}$ PH 101 merupakan produk asli yang diperoleh dengan cara hidrolisis asam dari selulosa murni, sedangkan Avicel ${ }^{\circledR}$ PH 102 merupakan produk aglomerasi dengan distribusi ukuran

partikel yang lebih besar (Landin et al., 2008).

Penelitian ini bertujuan mengevaluasi pengaruh bahan pengisi yaitu Avicel ${ }^{\circledR}$ PH 101 dan Avicel $^{\circledR}$ PH 102.terhadap massa cetak tablet vitamin C. Evaluasi yang dilakukan meliputi laju alir, sudut istirahat, carr's index, hausner ratio dan kelembaban.

\section{METODE PENELITIAN}

Penelitian ini dilakukan dari bulan November 2018 sampai Januari 2019, di laboratorium teknologi farmasi
Universitas Harapan Bangsa. Penelitian ini merupakan penelitian eksperimental, yaitu dengan melihat pengaruh penggunaan bahan pengisi pada massa cetak.

Alat-alat yang digunakan dalam penelitian ini adalah timbangan digital (Kenko), kaca arloji, mesh, cube mixer, gelas beaker, tapped density tester, gelas ukur, granul flow tester moisture balance apparatus

Bahan-bahan yang digunakan dalam penelitian ini adalah Avicel ${ }^{\circledR}$ PH 101 dan Avicel $^{\circledR}$ PH 102, Vitamin C, Amprotab, Magnesium Stearat dan Talk.

Prosedur penelitian dimulai dengan membuat formulasi dari massa cetak. Massa cetak dibuat dengan variasi pengisi yaitu Avicel $^{\circledR}$ PH 101 dan Avicel $^{\circledR}$ PH 102 kemudian dilakukan evaluasi dari massa cetak tersebut. Adapun Formula dari massa cetak yaitu:

Tabel 1. Formula variasi pengisi

\begin{tabular}{|c|c|c|}
\hline BAHAN & $\mathrm{F} 1$ & $\mathrm{~F} 2$ \\
\hline Vitamin C 75mg & $50 \%$ & $50 \%$ \\
\hline Amprotab & $5 \%$ & $5 \%$ \\
\hline Mg Stearat & $2 \%$ & $2 \%$ \\
\hline Talk & $5 \%$ & $5 \%$ \\
\hline Avicel PH 102 & $38 \%$ & $0 \%$ \\
\hline Avicel PH 101 & $0 \%$ & $38 \%$ \\
\hline
\end{tabular}


pengisi Avicel $^{\circledR}$ PH 101 dan Avicel $^{\circledR}$ PH 102, bahan disintegran (Amprotab), kemudian ditambahkan mg stearate dan talk. Campuran dari masing-masing formula dibuat dengan bobot tiap tablet adalah $150 \mathrm{mg}$.

Massa cetak kemudian di evaluasi yang meliputi pengujian kelembaban, laju alir, sudut istirahat, carr's index dan hausner ratio. Pengujian kelembaban dilakukan dengan menimbang 10 gram sampel, kemudian kelembaban dari sampel dibaca dengan alat moisture balance apparatus. Laju alir massa cetak ditentukan dengan mengggunakan granul flow tester. Masing-masing sampel ditimbang kemudian diletakan pada corong alat, waktu jatuhnya seluruh sampel dicatat untuk menentukan laju alir. Selain itu ketinggian dan diameter dari sampel yang jatuh melalui corong digunakan untuk penentuan sudut istirahat dari sampel. Selain penentuan laju alir dengan alat granul flow tester, sifat alir dari massa cetak ditentukan berdasarkan perhitungan sudut diam, carr's index dan hausner ratio.

Carr's index dan Hausner-ratio ditentukan dengan cara mengisikan masing-masing massa cetak ke dalam gelas ukur volume $100 \mathrm{~mL}$, setelah itu dengan menggunakan tapped density tester dilakukan penghentakan sebanyak 200 kali, dan diamati volume akhir serbuk. Carr's index dan Hausner ratio ditentukan dengan persamaan (1) dan (2).

Carr's index $=\frac{\rho \text { tapped }-\rho \text { bulk }}{\rho \text { tapped }} \times 100 \% \ldots$ (1)
Hausner ratio $=\frac{\rho \text { tapped }}{\rho \text { bulk }} \ldots \ldots \ldots$ (2)

Serbuk yang ada di dalam gelas ukur ditimbang bobotnya, kemudian dihitung bulk density ( $\rho$ bulk) dan tapped density ( $\rho$ tapped), seperti pada persamaan (3) dan (4).

Bulk density $=\frac{\text { berat serbuk }(\mathrm{gram})}{\text { Volume awal serbuk }(\mathrm{mL})} \ldots \ldots$. (3)

Tapped density $=\frac{\text { berat serbuk }(\mathrm{gram})}{\text { Vol setelah pengetapan }(\mathrm{mL})}$. (4)

Analisis data hasil evaluasi massa cetak dilakukan dengan uji Kolomogrov smirnov untuk menunjukan data terdistribusi normal atau tidak. Selanjutnya dilakukan dengan analisis varian satu arah (One Way Annova.) Menggunakan SPSS (Statistical Program for Social Scientific) versi 16. 


\section{HASIL DAN PEMBAHASAN}

Berdasarkan pengujian yang dilakukan laju alir untuk F1 dan F2 secara berturut yaitu $4,41 \pm 0,40 \mathrm{gram} / \mathrm{s}$ dan 2,76 $\pm 0,22$ gram $/ \mathrm{s}$. Menurut (Lachman, 2008) kemampuan mengalir serbuk dikatakan baik ketika > 10 gram/s.

Tabel 2. Hasil Evaluasi Massa Cetak

\begin{tabular}{lcc}
\hline Evaluasi & F1 & F2 \\
\hline Laju alir (gram/s) & $4,41 \pm 0,40$ & $2,76 \pm 0,22$ \\
Kelembaban (\%) & $0,28 \pm 0,03$ & $0,30 \pm 0,05$ \\
Sudut diam $\left(^{\circ}\right)$ & $22,40 \pm 1,12$ & $29,42 \pm 1,38$ \\
Carr's Index (\%) & $8,02 \pm 1,76$ & $15,82 \pm 1,39$ \\
Hausner Ratio & $1,13 \pm 0,02$ & $1,30 \pm 0,02$ \\
\hline
\end{tabular}

Kelembaban dari Formula F1 dan F2 secara berturut yaitu $0,28 \pm 0,03$ dan $0,30 \pm 0,05$. Massa cetak tersebut memenuhi persyaratan kelembaban, yaitu antara 3-5\% (Allison dan Laurent, 2014), jika kelembaban serbuk > 5\% maka akan mengalami kesulitan pada saat kompresi tablet, yaitu serbuk akan menempel pada punch dari mesin tablet sehingga tablet yang dihasilkan menjadi capping/picking.

Sudut diam dapat menjadi penentu kemampuan mengalir suatu serbuk. Sudut diam yang $<30^{\circ}$ menandakan sifat alir serbuk yang baik (Lachman, 2008). Berdasarkan Tabel 2 diketahui sudut diam dari kedua formula yaitu $22,40 \pm 1,12$ dan $29,42 \pm$ 1,38 .

Pengujian carr's index dilakukan untuk mengetahui sifat alir dari massa cetak. Semakin kecil pesentase kompresibilitas dari nilai $21 \%$ maka sifat alir serbuk makin baik (Azubuike dan Okhamafe, 2012). Berdasarkan Tabel 2 diketahui kedua Formula memiliki kompresibiltas $<21 \%$ yang mengindikasikan kemampuan alir dari massa cetak tersebut tergolong baik.

Pengujian Hausner Ratio dilakukan dengan membandingkan tapped density ( $\rho$ tapped) dengan bulk density ( $\rho$ bulk). Hasil yang diperoleh F1 yaitu 1,13 $\pm 0,02$ sedangkan $F 2$ 1,30 $\pm 0,02$. Syarat granul dapat mengalir dengan baik jika Hausner-ratio kurang dari 1,25 (Lachman, 2008). Berasarkan hasil yang diperoleh dari nilai Hausnerratio diketahui bahwa $\mathrm{F} 1$ memiliki kemampuan alir yang lebih baik daripada F2.

Hasil analisis dengan uji Kolmogorov-smirnov menunjukkan bahwa data evaluasi massa cetak 
terdistribusi normal dengan $p$-value > 0,05 . Untuk menganalisa ada tidakmya perbedaan nyata terhadap masingmasing parameter evaluasi, dilakukan uji Anova. Hasil uji menunjukkan bahwa ada perbedaan yang bermakna dari parameter laju alir $\mathrm{p}=0,04$, sudut diam $\mathrm{p}=0,02$, Hausner-ratio $\mathrm{p}=0,01$ dan carr's index $\mathrm{p}=0,01(\mathrm{p}<0,05)$.

Perbedaan hasil evaluasi dari massa cetak dapat terjadi karena variasi pengisi yang digunakan. Avicel ${ }^{\circledR} \mathrm{PH}$ 102 memiliki sifat alir yang lebih baik dari Avicel ${ }^{\circledR}$ PH 101. Penggunaan Avicel $^{\circledR}$ PH 102 pada pembuatan dengan metode cetak langsung akan lebih baik, karena memiliki ukuran partikel yang lebih besar, sehingga sifat alir Avicel $^{\circledR}$ PH 102 lebih baik dibandingkan Avicel $^{\circledR}$ PH 101. Selain itu, kompaktibilitas yang dimiliki Avicel $^{\circledR}$ PH sangat baik serta saat dikompresi dapat mengalami deformasi plastik yang dapat menyebabkan terjadinya interlocking, sehingga menyebabkan ikatan antar partikel yang kuat (Ohwoavworhua et al. 2007).

\section{SIMPULAN}

Berdasarkan penelitian yang telah dilakukan dapat disimpulkan bahwa massa cetak vitamin $\mathrm{C}$ yang menggunakan bahan pengisi Avicel ${ }^{\circledR}$ PH 102 menghasilkan granul yang lebih baik. Hal ini berdasarkan uji laju alir, sudut diam, carr's index dan hausner ratio.

Disarankan ada penelitian lanjutan mengenai uji sifat fisik dan keseragaman kadar tablet vitamin $\mathrm{C}$ dengan variasi pengisi Avicel ${ }^{\circledR}$ PH 102 dan Avicel ${ }^{\circledR}$ PH 101.

\section{DAFTAR PUSTAKA}

Allison dan Laurent (2014): The Effect of Moisture on the Flowability of Pharmaceutical Excipients. AAPS PharmaSciTech. doi: 10.1208/s12249-013-0036-0.

Azubuike CP dan Okhamafe AO (2012): Physicochemical, spectroscopic, and thermal properties of microcrystalline cellulose derivied from corn crobs. Int Recycling of Org Waste Agric. 1:1-9. doi:10.1186/22517715-1-9.

Gohel, M. C. 2005. A Review of Coprocessed Directly Compressible Excipients. J. Pharm Sci, Vol 8, no. 1: 76-93.

Lachman L., Lieberman, H.A., Kanig, J.L. (2008), The Theory and Practice of Industrial Pharmacy, 643-705, terjemahan Siti Suyatmi, Edisi ke-3, Jilid II, Universitas Indonesia Press, Jakarta.

Landín, M., P. González, Souto, Concheiro, Gómez-Amoza dan R. Martínez-Pacheco (2008): Comparison of two Varieties of 
Microcrystalline Cellulose as Filler-Binders

II. Hydrochlorothiazide Tablets. Journal Drug Development and Industrial Pharmacy. Volume 19, 1993 - Issue 10

Ohwoavworhua, F.O., Adelakun, T.A., and Kunle, O. O., 2007, A Comparative Evaluation of the Flow and Compaction Characteristics of á-Cellulose obtained from Waste Paper, Trop
J Pharm Res, March, 6 (1), 645651.

Rowe RC, Sheskey PJ, dan Quinn ME. (2009): Handbook of Pharmaceutical Excipient, 6th Edition. USA: American Pharmacist Association.

Siregar, C.J.P. dan Wikarsa, S. (2010):

Teknologi Farmasi Sediaan Tablet: Dasar-Dasar Praktis, Jakarta: EGC, Halaman 13-42. 